\title{
EFEITOS DO NCPC NA RECLAMAÇÃO EM MATÉRIA TRIBUTÁRIA
}

\author{
Alessandro Mendes Cardoso \\ Tatiana Rezende Torres
}

\section{INTRODUÇÃO}

O instituto da reclamação, positivado na Constituição Federal (CF) em seus art. 102, inciso I, alínea " $\mathrm{l}$ ", , e 105, inciso I, alínea "f", ${ }^{2}$ com o principal objetivo de preservação da competência e garantia da eficácia das decisões do Supremo Tribunal Federal (STF) e do Superior Tribunal de Justiça (STJ), sempre gerou debates na doutrina e na evolução da sua aplicação.

O seu processamento era regulado no Capítulo II da Lei n. 8.038/1990 e nos regimentos internos dos tribunais superiores. Com a evolução do sistema processual brasileiro, que privilegia a uniformização e a estabilização da jurisprudência, a Emenda Constitucional (EC) n. 45/2004 incluiu o art. 103-A na CF, posteriormente regulamentado pela Lei n. 11.417/2006, o qual prevê, em seu $\int 3^{\circ}, 3$ o

1 "Art. 102. Compete ao Supremo Tribunal Federal, precipuamente, a guarda da Constituição, cabendo-lhe: I - processar e julgar, originariamente: [...] l) a reclamação para a preservação de sua competência e garantia da autoridade de suas decisões; [...]."

2 "Art. 105. Compete ao Superior Tribunal de Justiça: I - processar e julgar, originariamente: [... f) a reclamação para a preservação de sua competência e garantia da autoridade de suas decisões; [...]."

3 "Art. 103-A. O Supremo Tribunal Federal poderá, de ofício ou por provocação, mediante decisão de dois terços dos seus membros, após reiteradas decisões sobre matéria constitucional, aprovar súmula que, a partir de sua publicação na imprensa oficial, terá efeito vinculante em relação aos demais órgãos do Poder Judiciário e à administração pública direta e indireta, nas esferas federal, 
cabimento de reclamação em face de "ato administrativo ou decisão judicial que contrariar a súmula aplicável ou que indevidamente a aplicar". E, uma vez provida pelo STF, a reclamação terá o condão de anular o ato administrativo, ou de cassar a decisão judicial reclamada, para que outra seja proferida em seu lugar, com ou sem a aplicação da súmula.

A constitucionalização da reclamação teve, portanto, três objetivos: (i) preservação da competência dos dois tribunais superiores; (ii) garantia da imperiosidade das decisões desses tribunais; e (iii) garantia da eficácia das súmulas vinculantes.

A partir da construção jurisprudencial do STF se identificam, como requisitos básicos para o processamento da reclamação, a existência de efetiva usurpação de competência ou descumprimento de decisão do STF ou STJ, ou a contrariedade à sumula vinculante. Para tanto, deve ser comprovada a identidade material entre a decisão objeto da reclamação e a decisão tida como contrariada (decisão paradigmática, que se busca garantir a eficácia), com o limitador objetivo de que a decisão reclamada não tenha transitado em julgado.

Sobre a natureza jurídica do instituto, há grande divergência doutrinária, com a defesa fundamentada de diversas classificações, como exemplifica decisão antiga do STF, proferida nos autos da Reclamação n. 336/DF, na qual o Ministro Relator Celso de Mello identifica sete classificações possíveis. ${ }^{4} \mathrm{O}$ certo é que a reclamação

estadual e municipal, bem como proceder à sua revisão ou cancelamento, na forma estabelecida em lei. [...] $\S 3^{\circ}$ Do ato administrativo ou decisão judicial que contrariar a súmula aplicável ou que indevidamente a aplicar, caberá reclamação ao Supremo Tribunal Federal que, julgando-a procedente, anulará o ato administrativo ou cassará a decisão judicial reclamada, e determinará que outra seja proferida com ou sem a aplicação da súmula, conforme o caso."

4 "RECLAMAÇÃO. NATUREZA JURÍDICA. ALEGADO DESRESPEITO A AUTORIDADE DE DECISÃO EMANADA DO STF. INOCORRÊNCIA. IMPROCEDÊNCIA. - A reclamação, qualquer que SEJA a qualificação que se the DE - Ação (Pontes de Miranda, "Comentários ao Código de Processo Civil", tomo V/384, Forense), recurso ou sucedâneo recursal (Moacyr Amaral Santos, RTJ 56/546-548; Alcides de Mendonca Lima, "O Poder Judiciário e a Nova Constituição", p. 80, 1989, Aide), remédio incomum (Orosimbo Nonato, "apud" Cordeiro de Mello, "O processo no Supremo Tribunal Federal", v. 1/280), incidente processual (Moniz de Aragão, "A Correição Parcial”, p. 110, 1969), medida de Direito Processual Constitucional (Jose Frederico Marques, "Manual de Direito Processual Civil", vol 3., 2. parte, p. 199, item n. 653, 9. ed., 1987, Saraiva) ou medida processual de caráter excepcional (Min. Djaci Falcão, RTJ 112/518-522) - configura, modernamente, instrumento de extração constitucional, inobstante a origem pretoriana de sua criação (RTJ 112/504), destinado a viabilizar, na concretização de sua dupla função de ordem político-jurídica, a preservação da competência e a garantia da autoridade das decisões do Supremo Tribunal Federal (CF, art. 102, I, "l”) e do Superior Tribunal de Justiça (CF, art. 105, I, "f"). - Não constitui ato ofensivo a autoridade 
se apresenta como exceção à lógica do sistema processual, que vincula qualquer pretensão contra atos judiciais aos meios recursais, previstos de forma taxativa pela legislação. Conforme destaca Lucas Buril de Macêdo, ${ }^{5}$

a reclamação é uma exceção a essa previsão, como o são os meios específicos de impugnação às decisões judiciais, que possuem eficácia preponderante constitutiva negativa ou mandamental, a depender da causa de pedir e do pedido, desfazendo o ato atacado ou determinando seja tomada certa providência pelo órgão judicial responsável pelo ato objeto da reclamação.

A análise aprofundada dessa questão foge ao objeto do presente artigo, mas, para simplificar, já que se encontra bastante consolidado o entendimento de que a reclamação não é sucedâneo recursal, existem duas classificações que possuem maior receptividade na melhor doutrina e na jurisprudência do STF. A primeira vê na reclamação um meio de exercício do direito constitucional de petição, posição acolhida pelo pleno do STF no julgamento da ADI n. 2.212/CE (Rel. Min. Ellen Gracie). A segunda corrente, que representa o entendimento majoritário da melhor doutrina, entende que a reclamação tem natureza de ação judicial de conhecimento com caráter mandamental, ${ }^{6}$ com base em argumentos que podem ser assim sintetizados: (i) é medida que depende de provocação de interessado, para o qual se exige capacidade de postular; (ii) provoca a cassação da decisão judicial reclamada por força da eficácia de decisão anterior, dotada de força hierárquica superior ou efeito vinculante; (iii) apresenta características da ação como causa de pedir e pedido, com a possibilidade de ser objeto de recurso e de produzir o efeito da coisa julgada.

Com a publicação da Lei n. 13.105/2015, que instituiu o Novo Código de Processo Civil (NCPC), inaugura-se uma nova fase para a reclamação, já que pela

de decisão emanada do Supremo Tribunal Federal o procedimento de magistrado inferior que, motivado pela existência de várias execuções penais ainda em curso, referentes a outras condenações não desconstituídas pelo "writ", deixa de ordenar a soltura imediata de paciente beneficiado por "habeas corpus" concedido, em caso diverso e especifico, por esta Corte" (Reclamação n. 336/DF, DJe: 15 mar. 1991).

5 MACÊDO, Lucas Buril de. Reclamação Constitucional fundada em precedentes obrigatórios no CPC/2015. In: GAIO JR., Antônio Ferreira; CÂMARA, Alexandre Freitas (Coord.). Código de Processo Civil: novas reflexões e perspectivas. Belo Horizonte: Del Rey, 2016. p. 212.

6 MEDINA, José Miguel Garcia; WAMBIER, Teresa Arruda Alvi. Recursos e ações autônomas de Impugnação. São Paulo: Revista dos Tribunais, 2013. 
primeira vez o instituto se encontra tipificado no códex processual. O NCPC trata da reclamação nos seus art. 988 a 993, inseridos no Livro III ("Dos processos nos tribunais e dos meios de impugnação das decisões judiciais”). Além da previsão expressa do instituto, o legislador ampliou as suas hipóteses de cabimento e detalhou regras procedimentais, conforme será abordado no próximo item.

A evolução do processo civil brasileiro já se fazia notar a partir da introdução no Código de Processo Civil de 1973 (CPC/73) dos institutos da repercussão geral (art. 543-A e 543-B, inseridos pela Lei n. 11.418/2006) e dos recursos repetitivos (art. 543-C, introduzido pela Lei n. 11.672/2008). Com o NCPC, o objetivo é a construção de um processo mais célere, justo, menos complexo e mais condizente com as nossas necessidades sociais, conforme explicitado na exposição de motivos do seu anteprojeto.

Como um dos mecanismos para a consecução desses desideratos, o NCPC visou combater a "dispersão excessiva da jurisprudência". Além de maior celeridade, os juristas que elaboraram o projeto entenderam que a consolidação jurisprudencial é mecanismo de promoção da igualdade entre os jurisdicionados. Para tanto, privilegiaram os instrumentos de pacificação jurisprudencial e julgamento vinculante, como é o caso da repercussão geral, e criaram o Incidente de Resolução de Demandas Repetitivas (IRDR).

Assim, é característica primordial do atual sistema processual a função do STF e do STJ de balizar o ordenamento jurídico, construindo uma jurisprudência que efetive os deveres de segurança jurídica, uniformidade e estabilidade. ${ }^{7}$ Nesse contexto é que se insere o novo regramento da reclamação, que, a partir do NCPC, tem a função relevante de ferramenta objetiva e ágil que permite ao jurisdicionado

7 "Por outro lado, haver, indefinidamente, posicionamentos diferentes e incompativeis, nos Tribunais, a respeito da mesma norma juridica, leva a que jurisdicionados que estejam em situações idênticas, tenham de submeter-se a regras de conduta diferentes, ditadas por decisões judiciais emanadas de tribunais diversos. Esse fenômeno fragmenta o sistema, gera intranquilidade e, por vezes, verdadeira perplexidade na sociedade. Prestigiou-se, seguindo-se direção já abertamente seguida pelo ordenamento jurídico brasileiro, expressado na criação da Súmula Vinculante do Supremo Tribunal Federal (STF) e do regime de julgamento conjunto de recursos especiais e extraordinários repetitivos (que foi mantido e aperfeiçoado) tendência a criar estímulos para que a jurisprudência se uniformize, à luz do que venham a decidir tribunais superiores e até de segundo grau, e se estabilize. Essa é a função e a razão de ser dos tribunais superiores: proferir decisões que moldem o ordenamento juridico, objetivamente considerado. A função paradigmática que devem desempenhar é inerente ao sistema" (Exposição de motivos do anteprojeto do NCPC). 
impugnar decisões que deixem de aplicar, ou apliquem de forma errônea, precedente judicial de vinculação obrigatória, ou súmula vinculante.

O direito tributário é uma das maiores fontes de ajuizamento de reclamação nos tribunais superiores, mesmo antes da introdução dos mecanismos supraindicados. O tratamento constitucional dado ao sistema tributário e a existência de lei complementar que trata das normas gerais de direito tributário (Código Tributário Nacional - CTN), além de leis complementares que delimitam os principais aspectos das normas de incidência tributária dos impostos, determinam que grande parte das demandas judiciais tributárias envolvam questões exclusivamente de direito, sobre competência e limites ao poder de tributar e aplicação dos princípios constitucionais tributários e das normas gerais de tributação, o que lhes remetem a serem apreciadas pelo STJ e/ou pelo STF.

E o grande volume de ações tributárias tratando da mesma matéria jurídica, com grande relevância social e econômica, tornaram esse ramo do direito o mais propício para a aplicação dos regimes da repercussão geral e dos recursos repetitivos. Segundo destaca Lívia Pinheiro Lopes, ${ }^{8}$

para comprovar esta realidade, qual seja, a especial vocação do ramo tributário à resolução de conflitos mediante a aplicação de mecanismos insertos na teoria dos precedentes, o desembargador federal Abraham ${ }^{9}$ fez um levantamento no ano de 2014 que englobou mais de 250 acórdãos de natureza vinculante. Sua pesquisa identificou que, do total de súmulas vinculantes editadas pelo STF, 25\% (ou 1/4) versam sobre Direito Tributário. Já com relação aos recursos extraordinários com repercussão geral reconhecida e julgados no mérito, 30\% (ou quase 1/3) são tributários. E este índice chega a 40\% em relação ao STJ, quando considerados os recursos especiais julgados sobre a sistemática repetitiva.

É exatamente a vocação da matéria tributária à resolução de grande parte dos conflitos entre contribuintes e fiscos, pelo sistema dos precedentes vinculativos,

8 LOPES, Livia Pinheiro. Precedentes vinculativos, direito tributário e o Novo CPC. In: DUARTE, Fernanda (Org.). A LEF e o Novo CPC: reflexões e tendências. O que ficou e o que mudará. Rio de Janeiro: Lumen Juris, 2016. p. 100-115.

9 ABRAHAM, Marcus; PEREIRA, Victor Pimentel. Jurisprudência Tributária Vinculante: teoria e Precedentes. São Paulo: Quartier Latin, 2015. 
que torna imperioso o conhecimento aprofundado da atual sistemática da reclamação no contencioso tributário.

\section{A RECLAMAÇÃO NO NCPC E O DIREITO TRIBUTÁRIO}

As hipóteses de cabimento da reclamação estão previstas no art. 988 do NCPC:

Art. 988. Caberá reclamação da parte interessada ou do Ministério Público para: I - preservar a competência do tribunal;

II - garantir a autoridade das decisões do tribunal;

III - garantir a observância de enunciado de súmula vinculante e de decisão do Supremo Tribunal Federal em controle concentrado de constitucionalidade; (Redação dada pela Lei nº 13.256, de 2016)

IV - garantir a observância de acórdão proferido em julgamento de incidente de resolução de demandas repetitivas ou de incidente de assunção de competência; (Redação dada pela Lei no 13.256, de 2016)

$\int 1^{\circ} \mathrm{A}$ reclamação pode ser proposta perante qualquer tribunal, e seu julgamento compete ao órgão jurisdicional cuja competência se busca preservar ou cuja autoridade se pretenda garantir.

$\int 2^{\circ} \mathrm{A}$ reclamação deverá ser instruída com prova documental e dirigida ao presidente do tribunal.

$\int 3^{\circ}$ Assim que recebida, a reclamação será autuada e distribuída ao relator do processo principal, sempre que possível.

$\int 4^{\circ}$ As hipóteses dos incisos III e IV compreendem a aplicação indevida da tese jurídica e sua não aplicação aos casos que a ela correspondam.

$\int 5^{\circ}$ É inadmissível a reclamação: (Redação dada pela Lei no 13.256 , de 2016)

I - proposta após o trânsito em julgado da decisão reclamada; (Incluído pela Lei no 13.256 , de 2016)

II - proposta para garantir a observância de acórdão de recurso extraordinário com repercussão geral reconhecida ou de acórdão proferido em julgamento de recursos extraordinário ou especial repetitivos, quando não esgotadas as instâncias ordinárias. (Incluído pela Lei n 13.256, de 2016) $\int 6^{\circ} \mathrm{A}$ inadmissibilidade ou o julgamento do recurso interposto contra a decisão proferida pelo órgão reclamado não prejudica a reclamação. 
A primeira hipótese de cabimento da reclamação diz respeito à preservação da competência do tribunal, ao qual é direcionada quando esta é efetivamente invadida. Exemplo de violação de competência seria o julgamento de pedido de declaração de inconstitucionalidade, com feição de controle abstrato e pretendido efeito erga omnes, por órgão que não o STF. Outro exemplo é a realização do juízo de admissibilidade do recurso de apelação pelo juízo de primeira instância, quando a competência é privativa do tribunal.

Outra hipótese é o manejo da reclamação para a garantia da autoridade das decisões do tribunal. É indiscutível que as decisões de tribunal, nos limites de sua competência, têm cumprimento e respeito obrigatórios por aqueles a ela submetidos. E quando, em uma situação concreta, ocorre o descumprimento de determinação jurisdicional expressa do tribunal, cabe reclamação para que este faça valer sua autoridade e sua eficácia. Ou seja, relaciona-se ao cumprimento das decisões proferidas pelas cortes, que não podem ser desconsideradas ou desrespeitadas por órgãos inferiores.

Recentemente, em processo no qual se discutia a exclusão do Imposto sobre Circulação de Mercadorias e Serviços (ICMS) da base de cálculo da contribuição ao Programa de Integração Social (PIS) e da Contribuição para o Financiamento da Seguridade Social (Cofins), a Fazenda Nacional interpôs Recurso Extraordinário (RE) contra acórdão proferido pelo TRF da $3^{a}$ Região. Em juízo de admissibilidade, foi proferida decisão monocrática que negou seguimento ao recurso, aplicando ao caso concreto o precedente do STF formado a partir do julgamento do RE n. 574.706, com repercussão geral reconhecida. Em face dessa decisão, a Fazenda Nacional interpôs agravo interno, requerendo que o processo fosse

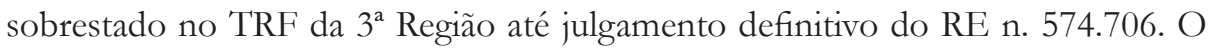
pedido da Fazenda Nacional foi indeferido, o que ensejou a propositura da Reclamação n. 30.996/SP ao STF.

A pretensão da Fazenda Nacional de concessão de tutela provisória em reclamação para que fosse determinado sobrestamento do RE até que definitivamente decidido o RE n. 574.706 se baseou no argumento de que o TRF da $3^{a}$ Região teria usurpado a competência do STF no que diz respeito à apreciação da modulação dos efeitos do acórdão proferido naquele julgamento. Também nesse ponto afirmou que o sobrestamento teria o condão de garantir a eficácia da decisão da suprema corte, que já teria sinalizado a possibilidade de modular os efeitos da decisão quando do julgamento dos embargos de declaração opostos pela Fazenda Nacional.

Ao apreciar a reclamação, o Relator Ministro Celso de Mello negou-lhe seguimento, entendendo não estarem presentes os requisitos que autorizariam a 
adequada utilização da reclamação. Segundo o relator, o ato reclamado não evidenciaria usurpação da competência,

nem sequer transgressão da autoridade do julgamento do RE $n^{\circ}$ 574.706, pois a decisão de que se reclama limitou-se a confirmar a aplicação do entendimento firmado pelo Supremo Tribunal Federal, em regime de repercussão geral, ao caso, tendo em vista a desnecessidade de aguardar-se o trânsito em julgado (ou eventual modulação temporal dos efeitos) do acórdão desta Suprema Corte invocado, pela parte reclamante, como paradigma de confronto. (Reclamação n. 30.996/SP, Rel. Min. Celso de Mello, DJe: 13 ago. 2018, publicado em: 14 ago. 2018)

O ministro relator ainda destacou que, de acordo com o entendimento do STF, "a circunstância de o precedente no 'leading case' ainda não haver transitado em julgado não impede venha o Relator da causa a julgá-la, fazendo aplicação, desde logo, da diretriz consagrada naquele julgamento", e que a modulação dos efeitos de decisões, por se tratar de medida excepcional, não se presume nem inibe o pronunciamento da maioria dos ministros, afastando, por essa razão, qualquer alegação de ofensa à autoridade dos julgados do STF ou de usurpação da sua competência que pudesse viabilizar o manejo da reclamação.

Sobre o uso da reclamação, o relator foi enfático ao afirmar que esse não é o meio processual correto para se buscar a revisão de atos decisórios, por não se qualificar como sucedâneo de outros recursos ou ações cabíveis. Confira-se trecho da decisão:

Cumpre enfatizar, de outro lado, por necessário, um outro aspecto que, assinalado em sucessivas decisões desta Corte, afasta a possibilidade jurídico-processual de emprego da reclamação, notadamente naqueles casos em que a parte reclamante busca a revisão de certo ato decisório, por entendê-lo incompatível com a jurisprudência do Supremo Tribunal Federal. Refiro-me ao fato de que, considerada a ausência, na espécie, dos pressupostos legitimadores do ajuizamento da reclamação, este remédio constitucional não pode ser utilizado como um (inadmissível) atalho processual destinado a permitir, por razões de caráter meramente pragmático, a submissão imediata do litígio ao exame direto da Suprema Corte.

A reclamação, como se sabe, reveste-se de múltiplas funções, tal como revelado por precedentes desta Corte (RTJ 134/1033, v.g.) e definido pelo novo 
Código de Processo Civil (art. 988), as quais, em síntese, compreendem (a) a preservação da competência global do Supremo Tribunal Federal, (b) a restauração da autoridade das decisões proferidas por esta Suprema Corte e (c) a garantia da observância da jurisprudência vinculante deste Tribunal Supremo (tanto a decorrente de enunciado sumular vinculante quanto a resultante dos julgamento desta Corte em sede de controle normativo abstrato), além de atuar como expressivo meio vocacionado a fazer prevalecer os acórdãos deste Tribunal proferidos em incidentes de assunção de competência.

Isso significa, portanto, que a reclamação não se qualifica como sucedâneo recursal, nem configura instrumento viabilizador do reexame do conteúdo do ato reclamado, nem traduz meio de uniformização de jurisprudência, eis que as finalidades revelam-se estranhas à destinação subjacente à instituição dessa medida processual, consoante adverte a jurisprudência do Supremo Tribunal Federal” (Reclamação n. 30.996/SP, Rel. Min. Celso de Mello, DJe: 13 ago. 2018, publicado em: 14 ago. 2018)

Mesmo que o NCPC tenha ampliado as hipóteses de cabimento da reclamação, essa decisão confirma a rigidez com que o STF analisará o seu cabimento, afastando toda e qualquer tentativa de fazer uso desse remédio como se recurso fosse.

No caso da súmula vinculante do STF (art. 988, inciso III), a possibilidade de se garantir a sua observância por meio de reclamação, por sua desconsideração ou aplicação equivocada por decisão judicial ou ato administrativo, se encontra constitucionalizada no $\int 3^{\circ}$ do art. 103-A, ${ }^{10}$ destacando-se que a jurisprudência do STF entende que somente cabe reclamação se a súmula é anterior ao ato reclamado. ${ }^{11} \mathrm{Da}$ mesma forma, nos termos do $\int 2^{\circ}$ do art. 102, a decisão do STF em controle concentrado de

10 "Art. 103-A. [...] § $3^{\circ}$ Do ato administrativo ou decisão judicial que contrariar a súmula aplicável ou que indevidamente a aplicar, caberá reclamação ao Supremo Tribunal Federal que, julgando-a procedente, anulará o ato administrativo ou cassará a decisão judicial reclamada, e determinará que outra seja proferida com ou sem a aplicação da súmula, conforme o caso."

11 "AGRAVO REGIMENTAL EM RECLAMAÇÃO. DIREITO PROCESSUAL CIVIL. HONORÁRIOS ADVOCATÍCIOS. SÚMULA VINCULANTE 47. ATO RECLAMADO ANTERIOR AO ADVENTO DO PARADIGMA. APLICABILIDADE DO ENUNCIADO SUMULAR AOS PRECATÓRIOS EXPEDIDOS ANTERIORMENTE. RECURSO POSTERIOR AO CPC/15. 1. A jurisprudência desta Corte é firme no sentido de que o cabimento da reclamação com parâmetro em Súmula Vinculante pressupõe a existência do paradigma anteriormente à decisão impugnada. Precedentes. 2. Não há identidade entre o enunciado sumular de índole vinculante e o ato reclamado, pois se entendeu neste que aquele não é aplicável retroativamente a abarcar precatórios expedidos antes do advento da 
constitucionalidade tem efeito erga omnes e vincula o poder judiciário, a administração pública e os demais jurisdicionados. Via de consequência, é cabível a reclamação em face de decisão que deixa de aplicá-la, ou o faz erroneamente.

Por outro lado, a decisão do STF proferida em controle difuso, pelo seu efeito interpartes, não viabiliza o seu manejo. Tal conclusão decorre da aplicação direta do inciso III do art. 988 do NCPC, que prevê a hipótese de cabimento da reclamação para fazer valer "decisão do Supremo Tribunal Federal em controle concentrado de constitucionalidade". Não obstante, deve-se aguardar o posicionamento do STF sobre a manutenção ou não do entendimento acerca da possibilidade do ajuizamento de reclamação em face de decisões em controle difuso, conforme anteriormente decidido nas Reclamações n. 4335 e n. 2280.

$\mathrm{Na}$ atual sistemática, a reclamação pode ser ajuizada em qualquer tribunal, não apenas nos superiores. Trata-se de inovação relevante, já que, no sistema processual anterior, o STF entendia que os tribunais de justiça somente poderiam processar e julgar reclamações se houvesse tal previsão nas respectivas constituições estaduais.

Posteriormente à edição do NCPC, o legislador, por meio da Lei n. 13.256/2016, impôs limites ao manejo da reclamação, com a inclusão do $\int 5^{\circ}$ na redação do art. 988. O inciso I do $\int 5^{\circ}$ diz respeito ao descabimento da sua propositura após o trânsito em julgado da decisão reclamada. Nesse ponto, o legislador confirmou o disposto na Súmula 734 do STF. ${ }^{12}$ Por outro lado, a inadmissibilidade ou o julgamento do recurso interposto contra a decisão reclamada não prejudica a propositura da reclamação (art. 988, $\left.\ 6^{\circ}\right)$.

Por meio do inciso II do $\int 5^{\circ}$, o legislador buscou evitar que a reclamação se tornasse meio substituto dos recursos regulares, determinando que a sua propositura, para STJ ou STF, contra descumprimento de decisão em recurso repetitivo ou com repercussão geral somente será possível após o exaurimento das instâncias ordinárias.

Alguns doutrinadores defendem que, em razão dos recursos excepcionais não se inserirem no conceito de "instâncias ordinárias", estariam fora do alcance do dispositivo, o que possibilitaria interpor a reclamação simultaneamente a esses recursos, ou quando ainda se encontrarem pendentes de apreciação. Contudo, a $2^{\mathrm{a}}$

Súmula Vinculante 47. 3. Agravo regimental a que se nega provimento" (Reclamação n. 23580 AgR /RS, DJe: 6 out. 2016, publicado em: 7 out. 2016).

12 "Não cabe reclamação quando já houver transitado em julgado o ato judicial que se alega tenha desrespeitado decisão do Supremo Tribunal Federal." 
Turma do STF se manifestou em sentido contrário ao indeferir reclamação interposta visando ao reconhecimento da prevalência de entendimento de RE com repercussão geral, em processo que ainda aguardava julgamento de RE e Recurso Especial (REsp). A Turma acompanhou o entendimento do Ministro Teori Zavascki, que assim se posicionou:

As razões recursais não conseguem infirmar esses fundamentos. Com efeito, pendentes de admissibilidade os recursos extraordinário e especial interpostos contra o acórdão que teria desrespeitado decisão desta Corte proferida sob o regime da repercussão geral, não está preenchida a exigência de esgotamento das instâncias ordinárias, daí porque a presente reclamação não se mostra cabível. Ora, o reclamante ainda tem a via recursal para buscar a reforma do acórdão questionado. Entendimento em sentido diverso permitiria a utilização da reclamação como atalho processual, contrariando a orientação consolidada pelo Plenário no julgamento da Rcl 10.793, Rel. Min. Ellen Gracie, DJe de 6/62011). (Reclamação n. 23.476/MS, julgado em: 2 ago. 16, DJe: 17 ago. 2016, publicado em: 18 ago. 2016)

Essa mesma necessidade de esgotamento das instâncias ordinárias impede a propositura de reclamação nos casos de: (i) suspensão errônea de processo, em função de afetação de recurso repetitivo, hipótese em que cabe à parte apresentar petição fazendo distinção entre os casos $\left(\operatorname{art} 1.037, \int 9^{\circ}\right)^{13}$ e, se mesmo assim for mantida a decisão, caberá agravo de instrumento ou interno, a depender a instância em que se encontra o processo; (ii) REsp ou RE indeferido em razão da errônea aplicação de julgado vinculativo (nesse caso será cabível agravo em REsp ou RE).

Os procedimentos para a propositura da reclamação não sofreram alterações relevantes. O legitimado para ajuizar é aquele que, tendo sofrido os efeitos de decisão ou ato que violou a competência do tribunal, ou desconsiderou a eficácia de decisão vinculante, tem interesse em exigir a preservação da competência usurpada. Na sistemática anterior, o STF diferenciava a legitimidade para interpor a reclamação conforme a natureza da sua decisão paradigma. Se proferida com efeito erga omnes e vinculante, a legitimidade seria ampla, não se limitando às partes

13 "§ $9^{\circ}$ Demonstrando distinção entre a questão a ser decidida no processo e aquela a ser julgada no recurso especial ou extraordinário afetado, a parte poderá requerer o prosseguimento do seu processo." 
processuais. Já no caso de decisão proferida em processo de controle difuso e com eficácia inter partes, apenas aqueles que compuseram a lide poderiam ajuizá-la. ${ }^{14}$

Recebida a reclamação, o relator solicitará informações à autoridade a quem se reputa a prática do ato violador da competência ou eficácia da decisão do tribunal, bem como determinará a citação do beneficiário da decisão impugnada, que terá o prazo de 15 dias para apresentar a sua contestação.

A inicial da reclamação deverá ser instruída com os documentos referentes ao seu objeto, principalmente as cópias da decisão ou ato reclamado e da decisão desrespeitada. Pela sua natureza, a reclamação não demanda outra prova que não a documental. A medida deve ser dirigida ao presidente do tribunal e, depois de autuada, será distribuída ao relator do processo principal, caso isso seja possível (art. 988, $\iint 2^{\circ}$ e $\left.3^{\circ}\right) .{ }^{15}$ Qualquer pessoa que tenha efetivo interesse no seu resultado poderá ingressar e impugná-la (art. 990). ${ }^{16}$ Além disso, avaliando que a manutenção da decisão ou do ato impugnado poderá gerar dano irreparável ao reclamante, o relator poderá determinar a suspensão da sua eficácia (art. 989, inciso II) ${ }^{17}$

14 "RECLAMAÇÃO CONSTITUCIONAL. ALEGADA VIOLAÇÃO DE AUTORIDADE DE PRECEDENTE DO PLENO DO SUPREMO TRIBUNAL FEDERAL. ARESTO FIRMADO EM JULGAMENTO DE ALCANCE SUBJETIVO. AGRAVO DE INSTRUMENTO. LEGITIMIDADE PARA PROPOR A RECLAMAÇÃO. PROCESSUAL CIVIL. AGRAVO REGIMENTAL. DECISÃO QUE INDEFERE DE PLANO O SEGUIMENTO DA RECLAMAÇÃO. 1. Agravo regimental interposto de decisão com a qual se negou seguimento à reclamação, destinada a assegurar a autoridade de precedente da Corte. 2. A reclamação não é instrumento de uniformização jurisprudencial. Tampouco serve de sucedâneo de recurso ou medida judicial cabivel para fazer valer o efeito devolutivo pretendido pelo jurisdicionado. 3. Nos termos da orientação firmada pelo Supremo Tribunal Federal, são legitimados à propositura de reclamação todos aqueles que sejam prejudicados por atos contrários às decisões que possuam eficácia vinculante e geral (erga omnes). Se o precedente tido por violado foi tomado em julgamento de alcance subjetivo, como se dá no controle difuso e incidental de constitucionalidade, somente é legitimado ao manejo da reclamação as partes que compuseram a relação processual do aresto. 4. No caso em exame, o reclamante não fez parte da relação processual em que formado o precedente tido por violado (agravo de instrumento julgado pelo Pleno do Supremo Tribunal Federal). Agravo regimental conhecido, mas ao qual se nega provimento" (Reclamação n. 6078 AgR, Pleno, Rel. Min. Joaquim Barbosa, julgado em: 8 abr. 2010, DJe: 29 abr. 2010).

“Art. 998. [...] § $2^{\circ}$ A reclamação deverá ser instruída com prova documental e dirigida ao presidente do tribunal. $\S 3^{\circ}$ Assim que recebida, a reclamação será autuada e distribuída ao relator do processo principal, sempre que possivel." "Art. 990. Qualquer interessado poderá impugnar o pedido do reclamante."

17 "Art. 989. Ao despachar a reclamação, o relator: I - requisitará informações da autoridade a quem for imputada a prática do ato impugnado, que as prestará no prazo de 10 (dez) dias; II - se 
Julgada procedente a reclamação, o órgão julgador determinará a cassação da decisão ou do ato reclamado, reconhecendo a invasão da competência ou o desrespeito a decisão do tribunal, ou, ainda, que houve afronta a decisão do STF proferida em sede de controle concentrado, desrespeito a enunciado de súmula vinculante ou inobservância de acórdão proferido em julgamento de incidente de resolução de demandas repetitivas ou de incidente de assunção de competência. Além da cassação do ato reclamado, o NCPC permite que seja determinada outra medida adequada à solução da controvérsia.

O NCPC absorve a evolução legislativa e doutrinária que vinha se consolidando no país, com o objetivo de construir um sistema de precedentes vinculativos, buscando combater a realidade nacional de falta de consolidação da jurisprudência, multiplicidade de entendimentos sobre a mesma matéria jurídica e desrespeito sistemático ao entendimento "consolidado" dos tribunais, inclusive por eles mesmos. Essa realidade fica muito evidente na área tributária: era notória a dificuldade dos tribunais superiores, notadamente do STJ, em consolidar entendimento acerca de teses tributárias e garantir a sua aplicação uniforme pelas cortes e instâncias inferiores. Isso, aliado à demora no julgamento das teses tributárias, elevavam o nível de insegurança jurídica, contribuindo para a visão de que o sistema tributário brasileiro é caótico.

Atualmente, mesmo que em patamares menores, ainda é possível identificar, nas duas Seções de Direito Público do STJ, decisões que conflitam entre si, com decisões da $1^{\text {a }}$ Seção ou ainda com anteriores decisões proferidas em sede de recursos repetitivos. Também não é incomum precedentes de Turmas que alteram entendimentos já consolidados há anos no tribunal, produzindo efeitos relevantes e prejudiciais para contribuintes e fiscos vinculados à matéria decidida.

A situação de insegurança jurídica também se vislumbra na jurisprudência do STF. Como exemplo, o pleno do STF, ao julgar o RE n. 593.894, alterou o entendimento exteriorizado na Ação Direta de Inconstitucionalidade (ADI) n. 1.851/SP para reconhecer o direito dos contribuintes substituídos de recuperar os valores da substituição tributária de ICMS correspondente entre a base de cálculo presumida e a real do imposto, mudança jurisprudencial que deverá ter grandes impactos financeiros para os estados.

necessário, ordenará a suspensão do processo ou do ato impugnado para evitar dano irreparável; III - determinará a citação do beneficiário da decisão impugnada, que terá prazo de 15 (quinze) dias para apresentar a sua contestação." 
Apesar de ser inegável que a sistemática do NCPC é um avanço importante para a evolução do sistema jurídico brasileiro, é também imprescindível que a sua aplicação pelos operadores do direito, notadamente os julgadores, ocorra de forma coerente, evitando-se que o objetivo de celeridade e simplificação implique a perda de qualidade da análise jurídica.

O ponto inicial e primordial é o correto entendimento do que constituem precedentes judiciais. Para tanto, nos valemos da doutrina de Lucas Buril de Macedo: ${ }^{18}$

Para o direito, os precedentes, mais propriamente os judiciais, "são resoluções em que a mesma questão jurídica, sobre a qual há que decidir novamente, já foi resolvida uma vez por um tribunal noutro caso". São, do ponto de vista prático, decisões anteriores que sevem como ponto de partida ou modelo para as decisões subsequentes. Nesse sentido o precedente judicial abarca toda a decisão - relatório, fundamentos e dispositivo. Precedente é fonte de direito, ou seja, é fato jurídico continente de uma norma jurídica. É dizer, a partir do precedente, através do trabalho dos juízes subsequentes, dar-se-á uma norma geral. Dessa forma, precedente é continente, é forma e não se confunde com a norma que dele exsurge. Com efeito, trata-se de instrumento para a criação de normas mediante o exercício da jurisdição. [...]

É importante perceber que há diferenças entre a decisão, e até mesmo a sua fundamentação, e o precedente em sentido estrito, que constitui uma norma compreendida a partir de toda a decisão, por um processo construtivo próprio, e a ela não se limita. Esse seria o conceito estrito de precedente, que se confunde com o de ratio decidendi ou norma de decisão. É nesse sentido que se fala, por exemplo, em "aplicação do precedente": o que se está a aplicar, a rigor, é a norma que se constrói a partir do precedente.

Para a eficácia do sistema baseado em precedentes, é imprescindível que os julgadores tenham bastante consolidado que este é centrado na delimitação das teses jurídicas fixadas nos julgamentos dotados de efeito vinculante. A ratio decidendi dos precedentes deve exteriorizar um comando que, de forma clara e objetiva, resolva determinada questão jurídica, de forma a possibilitar que seja aplicado em todos

18 MACÊDO, Lucas Buril de. Reclamação Constitucional fundada em precedentes obrigatórios no CPC/2015. In: GAIO JR., Antônio Ferreira; CÂMARA, Alexandre Freitas (Coord.). Código de Processo Civil: novas reflexões e perspectivas. Belo Horizonte: Del Rey, 2016. p. 207-208. 
os demais processos que tratem da mesma matéria. Por isso, os julgadores devem ter extremo cuidado ao delimitar a tese jurídica que está sendo apreciada no julgamento que gerará precedente vinculativo. E a decisão final deverá trazer, em seu dispositivo, as razões determinantes para aquele resultado. Serão essas razões determinantes que irradiarão, a partir do precedente, um comando jurisprudencial que terá eficácia de norma jurídica, vinculando objetivamente a forma de decidir outros casos similares.

Outro desafio é o aprimoramento da aplicação dos precedentes vinculativos. A operacionalização do sistema de precedentes implica a correta aplicação da técnica da distinção (distinguishing). Conforme leciona Lucas Buril de Macedo, ${ }^{19}$

nas distinções o jurista opera através do raciocínio analógico entre os fatos do precedente e os do caso presente, identificando quais as diferenças e similitudes, demonstração que são substanciais, ou seja, que são juridicamente relevantes [...] ou seja, a fim de aplicar precedentes, mais propriamente determinar se um precedente é aplicável a um caso subsequente, é preciso observar os fatos que foram decisivos para que a decisão anterior fosse efetivamente prolatada e, em seguida, analisar as similitudes com o caso subsequente, especificando se os fatos categorizados que foram considerados juridicamente importantes estão presentes e quais fatos não possuem relevância para o direito.

Tendo em vista as possibilidades restritas de recurso em face das decisões que aplicam precedentes vinculativos a outros casos, os órgãos julgadores deveriam ter o máximo critério nessa atividade. Contudo, tem sido usual a identificação de aplicação equivocada de precedentes vinculativos a casos posteriores que tratam de questão jurídica diversa e, o que é pior, a consolidação dessa aplicação errônea, exatamente pela dificuldade recursal em se fazer rever o ato original de aplicação de precedente.

A matéria tributária, pelas suas peculiaridades, é terreno fértil para a resolução de questões pela sistemática dos precedentes vinculativos. Isso porque grande parte das ações tributárias envolve discussões exclusivamente de direito, centradas na correta aplicação do sistema constitucional tributário, do CTN e

19 MACÊDO, Lucas Buril de. Reclamação Constitucional fundada em precedentes obrigatórios no CPC/2015. In: GAIO JR., Antônio Ferreira; CÂMARA, Alexandre Freitas (Coord.). Código de Processo Civil: novas reflexões e perspectivas. Belo Horizonte: Del Rey, 2016. p. 210. 
das leis complementares que instituem as normas básicas para a incidência dos impostos. A natureza dessas ações faz com que sejam replicadas em massa, já que se aplicam a inúmeros contribuintes sujeitos à mesma incidência. E a centralidade da discussão constitucional e da aplicação das leis complementares tributárias determina que essas demandas tenham a sua análise final efetuada pelo STF e/ou pelo STJ.

Ainda há situações em que a mesma matéria será analisada pelo STJ, na sistemática dos recursos repetitivos, e pelo STF, com repercussão geral. Exemplo relevante é a discussão sobre o terço constitucional de férias pago ao empregado integrar ou não o salário de contribuição, base de cálculo das contribuições previdenciárias sobre a remuneração. Nesses casos, o STF já decidiu que não cabe reclamação contra decisão que aplicou decisão de recurso repetitivo se a matéria ainda aguarda julgamento pelo próprio STF. A conclusão da suprema corte é explicitada na seguinte passagem do voto do Ministro Edson Fachin, relator do Agravo Regimental (AgRg) na Reclamação n. 16.969/SP:

Ademais, como já posto na decisão recorrida, não se verifica qualquer usurpação da competência desta Corte, uma vez que o recurso extraordinário e o recurso especial possuem objetos distintos, violação à Constituição da República e à legislação federal, respectivamente, o que se reflete na aplicação individualizada das sistemáticas da repercussão geral e do recurso repetitivo. (Reclamação n. 16969 AgR /SP, julgamento em: 23 ago. 16, DJe: 14 set. 2016, publicado em: 15 set. 2016)

Espera-se que a sistemática do NCPC, cujas repercussões já se fazem notar, reduza a litigiosidade em matéria tributária, com contribuintes e fisco tendo maior segurança na interpretação da legislação. A certeza sobre a tributação incidente em determinado fato ou operação, e a correta interpretação da legislação tributária pertinente, é elemento estabilizador, que produz efeito relevante nas relações econômicas tanto para contribuintes, que conseguem planejar melhor as suas atividades, quanto para as Fazendas Públicas, que terão maior previsibilidade nos ingressos de recursos fiscais, o que lhes permitirá planejar melhor o seu orçamento e os gastos públicos.

O aperfeiçoamento do uso da reclamação, trazido pelo NCPC, está inserido nesse contexto de valorização do papel dos precedentes, visando à construção de um sistema com maior segurança jurídica e racionalidade na aplicação do direito. 


\section{CONSIDERAÇÕES FINAIS}

A regulamentação da reclamação constitucional pelos art. 988 a 993 do NCPC ampliou as hipóteses do seu cabimento, privilegiando o objetivo que norteia o novo códex de instituir um processo mais célere, justo, menos complexo e mais condizente com as nossas necessidades sociais, como forma de pacificação jurisprudencial e julgamento vinculante.

De acordo com o NCPC, a reclamação é cabível para preservar a competência do tribunal e garantir a autoridade das decisões do tribunal e a aplicação de súmula vinculante e de decisão do STF proferida em sede de controle concentrado de constitucionalidade, além de garantir a observância de acórdãos proferidos em julgamentos de IRDR ou incidente de assunção de competência.

Atualmente, pode ser ajuizada em qualquer tribunal, não apenas nos superiores. Trata-se de inovação relevante, já que no sistema processual anterior, o STF entendia que os tribunais de justiça somente poderiam processar e julgar reclamações se houvesse tal previsão nas respectivas constituições estaduais.

Ainda que o NCPC tenha ampliado as hipóteses de cabimento da reclamação, o STF vem analisando de forma rígida o seu cabimento, afastando toda e qualquer tentativa de fazer uso desse remédio como se recurso fosse.

Posteriormente à edição do NCPC, a Lei n. 13.256/2016 impôs limites ao manejo da reclamação, que não pode ser proposta após o trânsito em julgado da decisão reclamada ou antes do exaurimento das instâncias ordinárias, para garantir a observância de acórdão proferido em sede de repercussão geral ou de recursos repetitivos. Essa necessidade de esgotamento das instâncias ordinárias também impede a propositura de reclamação nos casos de: (i) suspensão errônea de processo em função de afetação de recurso repetitivo, hipótese em que é cabível a apresentação de simples petição fazendo distinção entre os casos (artigo 1.037, $\left.\llbracket 9^{\circ}\right)$ e, se mesmo assim for mantida a decisão, caberá agravo de instrumento ou interno, a depender a instância em que se encontra o processo; (ii) recurso especial ou extraordinário indeferido em razão da errônea aplicação de julgado vinculativo (nesse caso será cabível agravo em REsp ou RE).

A reclamação tem papel relevante em matéria tributária, que, pela sua natureza, é terreno fértil para a resolução de questões pela sistemática dos recursos repetitivos ou com repercussão geral. Grande parte das ações tributárias tem como objeto discussões exclusivamente de direito, centradas na correta aplicação do sistema constitucional tributário, do CTN e das leis complementares que instituem as normas básicas para a incidência dos impostos. Além disso, a natureza dessas 
ações faz com que sejam replicadas em massa, já que se aplicam a inúmeros contribuintes sujeitos à mesma incidência. E a centralidade da discussão constitucional e da aplicação das leis complementares tributárias determina que essas demandas tenham a sua análise final efetuada pelo STF e/ou pelo STJ.

Apesar de a sistemática do CPC/15 ser um importante avanço, há desafios sistêmicos imprescindíveis para que o sistema de decisões vinculantes produza os efeitos pretendidos, como a correta criação de precedentes com eficácia vinculativa, cabendo aos julgadores o cuidado ao delimitar a tese jurídica que está sendo apreciada no julgamento que gerará precedente vinculativo, e o aprimoramento da aplicação dos precedentes vinculativos pela técnica da distinção (distinguishing). 